\section{Intersections}

Canadian Journal of Music

Revue canadienne de musique
Intersections CANADIAN JOURAL OF MUSIC

\title{
Marcel Dupré's “Dark Years”: Unveiling His Occupation-Period Concertizing
}

\section{Lynn Cavanagh}

Volume 34, numéro 1-2, 2014

URI : https://id.erudit.org/iderudit/1030869ar

DOI : https://doi.org/10.7202/1030869ar

Aller au sommaire du numéro

\section{Éditeur(s)}

Canadian University Music Society / Société de musique des universités canadiennes

ISSN

1911-0146 (imprimé)

1918-512X (numérique)

Découvrir la revue

Citer cet article

Cavanagh, L. (2014). Marcel Dupré's “Dark Years”: Unveiling His

Occupation-Period Concertizing. Intersections, 34(1-2), 33-57.

https://doi.org/10.7202/1030869ar
Résumé de l'article

Un examen des programmes de concert de l'organiste Marcel Dupré révèle que sur 137 concerts donnés pendant l'occupation allemande, 14 semblent avoir été financés par l'ambassade allemande ou par le département de la propagande du gouvernement militaire. Pourtant, Dupré aurait participé aussi à l'expression d'une bonne conscience nationale à travers sa fierté personnelle pour le passé musical français. Les condamnations des musiciens « ayant collaboré avec l'ennemi » pendant la période post-libération n’ayant pas été effectuées systématiquement, Dupré semble avoir masqué l'étendue et la nature de ses activités de concert pendant l'occupation. Ce portait plus complet de ses activités permet de renouveler notre compréhension de ses compositions pendant la Deuxième uerre mondiale, en particulier sa pièce Évocation, op.37.
Copyright @ Canadian University Music Society / Société de musique des universités canadiennes, 2015
Ce document est protégé par la loi sur le droit d'auteur. L'utilisation des services d’Érudit (y compris la reproduction) est assujettie à sa politique d'utilisation que vous pouvez consulter en ligne.

https://apropos.erudit.org/fr/usagers/politique-dutilisation/ 


\title{
MARCEL DUPRÉ'S “DARK YEARS”: UNVEILING HIS OCCUPATION-PERIOD CONCERTIZING ${ }^{1}$
}

\author{
Lynn Cavanagh
}

The 1940-44 German occupation of France remained for the next thirty years an obscure episode of French history, so rarely written of as to suggest it had never occurred (Jackson 2001, 1-2). In the mid-1970s, though, French historians began to describe its facets: life under the German military government; the Vichy regime that purportedly governed the unoccupied zone; the treatment of French Jews; and patterns of cooperation with, and resistance to, German military rule. In the late 1980 os scholarly studies of the period's art, theatre, and filmmaking began to appear. ${ }^{2}$ The first studies of musical activity in Occupation-period France appeared at the start of the twenty-first century: essays published under the title La Vie musicale sous Vichy reveal the plenitude of professional musicians' solo and ensemble concertizing during the Occupation and the large numbers in which the general public attended (Chimènes 2001). These revelations are in strong contrast to the impression given by individual twentieth-century French musicians' biographies written prior to 1990, which in almost all cases avoid mention of the musicians' public performances during the years 1940 to 1944 , as if their concert-giving came to a virtual standstill during that time.

Michael Murray's 1985 biography of organist-composer Marcel Dupré (18861971 ), with whom he studied organ for two years during the early 1960s, grew from his written notes of Dupré's answers to his questions during the same years (Murray 1985, xx). Concerning his Second World War period, the biography summarizes Dupré's composition and editing projects, then footnotes his concertizing as "some twenty programs, most in Meudon [Paris suburb where he lived] and Rouen [his birthplace] and most benefits for students ... and for prisoners of war" (Murray 1985, 184n4). This statement is belied by the evidence of Dupré's collection of printed concert programs, the existence of which Murray was aware (Murray 1985, 224). ${ }^{3}$ As documented in this collection, concerts

1 This article began as a presentation for the April 2012 conference of the Pacific Northwest chapter of the American Musicological Society at the University of Alberta in Edmonton. The "veil" metaphor to describe the Second World War period of Marcel Dupré's life is borrowed from Dupré scholar Graham Steed (Steed 1979, 36). The phrase "the dark years" to describe the 1940-44 period of French history was first popularized by publication of Jean Guéhenno's Journal des années noires.

2 For a bibliography of studies of France's cultural life during the Occupation, see Jackson 2001, 642 .

3 When asked about the discrepancies, Murray avoided explanation of how they came about but declared, "I'm very glad to have the record set straight," and graciously encouraged the present project. Murray in e-mail correspondence with the author, 2 July 2012. 
for the period June 1940 through August 1944 alone number 137-the majority without any indication of charitable purpose-and took place throughout France. ${ }^{4}$ Even more problematically, included in these 137 are seven programs recorded for broadcast on Radio-Paris (then an arm of the Nazi Propaganda Department), three recitals performed in Lucerne, Switzerland, for a 1942 German-French-Italian music festival, and four live engagements in Occupied France that bear evidence of Nazi cultural propaganda alongside signs of Duprés own French musical patriotism. In these fourteen Occupation-period performances, was Dupré a "collaborator with the enemy" or was he a champion of French musical culture? If the latter, why would he and his biographer suppress the extent and nature of his wartime concertizing? In the end, why should Dupré scholars be interested in setting the record straight?

Towards answering these questions, part 1 of this article examines five programs from Dupré's files from the Occupation years-the four live concerts in France that evoke suspicion of complicity with Nazi cultural propaganda, and a representative program performed for Radio-Paris. It will be demonstrated that the live concerts too were likely organized and funded by Nazi-controlled organizations, that Dupré was engaged because he was well known in France, and that he would have participated in good conscience out of personal pride in the French cultural achievements showcased in these events. In part 2, comparison of ways in which the word collaborator has been applied will demonstrate the futility of attempting a moral judgment upon Duprés decisions to cooperate with German organizers of these events. Following that, a survey of sanctions and punishments imposed on French musicians who were named during the post-Liberation period as having collaborated with the enemy will suggest why Dupré, in his postwar interviews and memoirs, suppressed the extent and nature of his Occupation-period concertizing originally undertaken in good conscience. In conclusion, part 3 will demonstrate how this fuller picture of the Second World War period of Marcel Dupré's career may shed light on his Second World War period composition projects.

\section{Part 1: Five Concert Programs, Dated June 1941 to August 1944}

Table 1 compiles dates, titles, venues and other performers' names transcribed from the five printed programs. The program leaflets for the selected choir and organ concerts were printed with French and German versions on separate sides or pages, a format not found in any other of the one hundred thirty-seven programs Dupré preserved from this period (see figures 1 and 2 for a facsimile example). The source of information for the 15 January 1942 broadcast performance is Dupré's handwritten note, filed chronologically with the printed programs for live events. 5

The note concerning the broadcast recital specifies it was heard on RadioParis, but none of the programs for the selected live concerts mentions under

4 Bibliothèque nationale de France, Marcel Dupré Papers, cote Vma 2803, boîte 6, \#1303-1439.

5 Bibliothèque nationale de France, cote Vma 2803, boîte 6. 
Table 1. Dates, titles, venues, and other performers from five Marcel Dupré programs

\begin{tabular}{|c|c|c|c|c|c|}
\hline $\begin{array}{l}\text { Date, time, and title on } \\
\text { printed program }\end{array}$ & $\begin{array}{c}1 \text { June } 1941 \text { (Sunday) 8:00 } \\
\text { p.m. } \\
\text { Concert de Musique Sacrée } \\
\text { Musikalische Feierstunde }\end{array}$ & $\begin{array}{c}6 \text { December } 1941 \\
\text { (Saturday) 6:00 p.m. } \\
\text { Concert de Musique } \\
\text { Religieuse }\end{array}$ & $\begin{array}{c}15 \text { January } 1942 \text { (Thursday) } \\
\text { 10:15 a.m. } \\
\text { Dupré's handwritten note }\end{array}$ & $\begin{array}{c}12 \text { March } 1942 \\
\text { (Thursday) 6:30 p.m. } \\
\text { Concert de Musique } \\
\text { Religieuse }\end{array}$ & $\begin{array}{l}13 \text { August } 1944 \\
\text { (Sunday) 5:30 p.m. } \\
\text { Quatrième Récital d'Orgue }\end{array}$ \\
\hline Venue & $\begin{array}{l}\text { Notre Dame Cathedral, } \\
\text { Amiens }\end{array}$ & $\begin{array}{l}\text { Notre Dame Cathedral, } \\
\text { Paris }\end{array}$ & St. Sulpice, Paris & $\begin{array}{l}\text { Notre Dame Cathedral, } \\
\text { Paris }\end{array}$ & $\begin{array}{l}\text { Notre Dame Cathedral, } \\
\text { Paris }\end{array}$ \\
\hline $\begin{array}{l}\text { On the same program with } \\
\text { Marcel Dupré }\end{array}$ & $\begin{array}{l}\text { - Choir of soldiers and } \\
\text { ladies of the German Red } \\
\text { Cross } \\
\text { - Soprano Anne-Marie } \\
\text { Bernard (soloist with Les } \\
\text { grands concerts sympho- } \\
\text { niques de Paris) }\end{array}$ & $\begin{array}{l}\text { - Bremen Cathedral Choir } \\
\text { - Conductor Richard } \\
\text { Liesche }\end{array}$ & N/A & $\begin{array}{l}\text { - Vienna Boys' Choir } \\
\text { - Conductor Ferdinand } \\
\text { Grossman (of Vienna) }\end{array}$ & $\begin{array}{l}\text { One organ recital in a July- } \\
\text { August series, including } \\
\text { - Léonce de St-Martin, } \\
\text { titular organist } \\
\text { - Joseph Tönnes } \\
\text { - Fritz Werner } \\
\text { - Joseph Ahrens }\end{array}$ \\
\hline
\end{tabular}




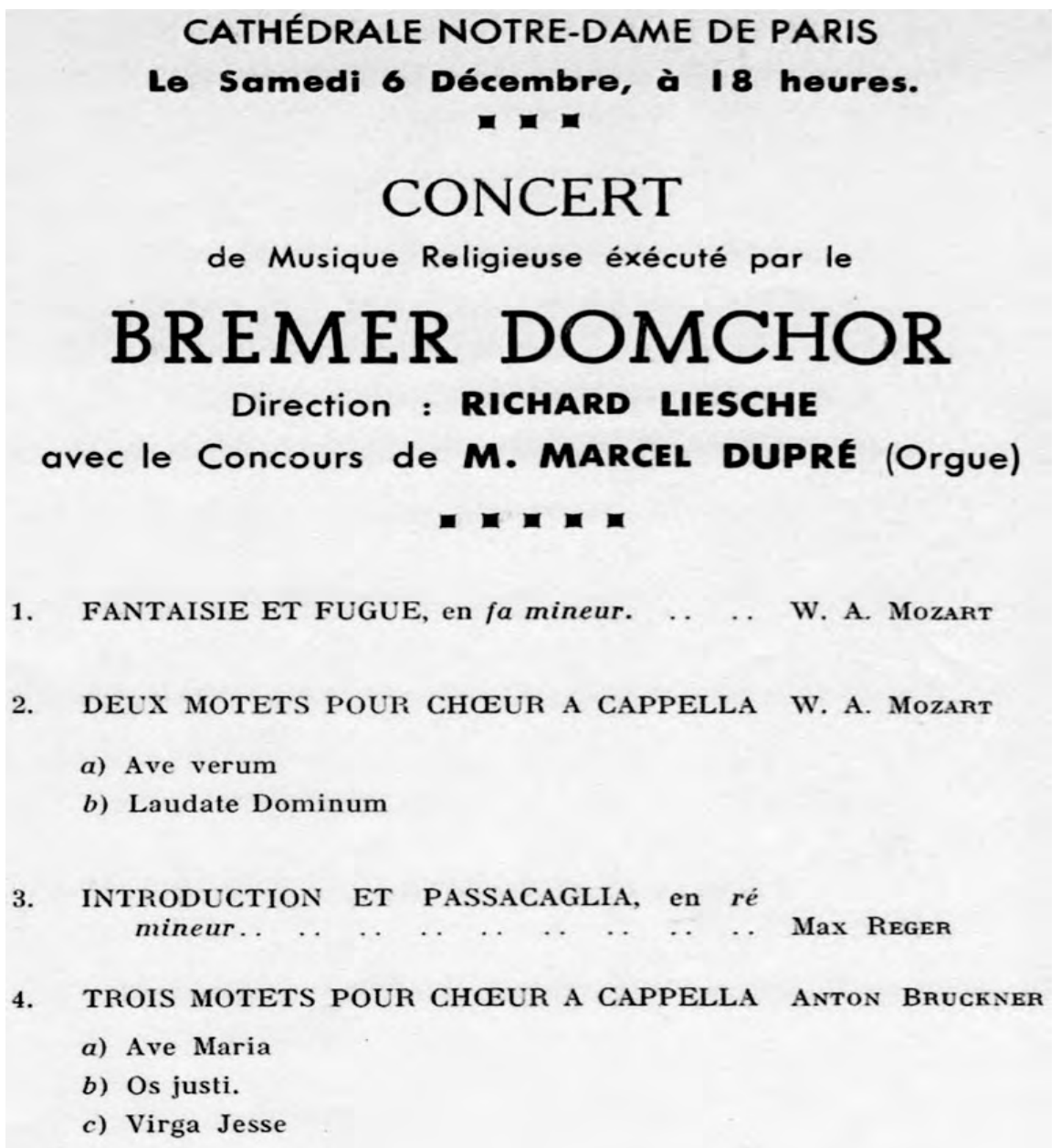

5. MOTET POUR DOUBLE CEEUR, à huit voix.. J. S. Bach «Viens, Jésus, viens \$

6. PRelude et fugue, en sol majeur.. . . . . J. S. Bach

\section{ENTRÉE LIBRE.}

Figure 1. French-language side of 6 December 1941 program. Bibliothèque national de France, Marcel Dupré Papers, Vma 2803, boîte 6, \#1319. Used by permission. 


\section{KATHEDRALE NOTRE-DAME DE PARIS}

Sonnabend, den 6 Dezember 1941 um 18 Uhr.

\section{MOTETTE}

Ausfuehrende :

\section{DER BREMER DOMCHOR Unter der Leitung von RICHARD LIESCHE MARCEL DUPRE (Orgel)}

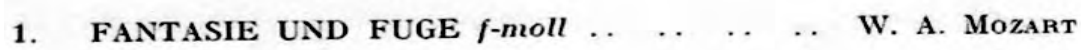

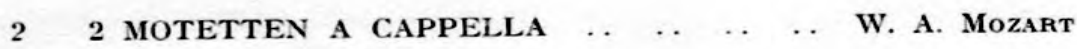

a) Ave verum

b) Laudate Dominum

3 INTRODUCTION UND PASSACAGlia $d$-moll.. Max Reger

4. 3 MOtetten a CAPpella. $\ldots$.
a) Ave Maria
b) Os justi
c) Virga Jesse

5. Komm, Jesu, komm \. MOTETTE FUER

8-stimmigen Doppelchor. ..

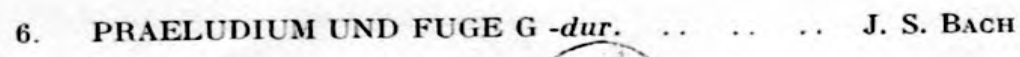

\section{EINTRITT FREI.}

Figure 2. German-language side of 6 December 1941 program. Vma 2803, boîte 6, \#1319. Bibliothèque national de France, Marcel Dupré Papers, \#1319. Used by permission. 
whose auspices it was held. It is suggestive that all four took place in one or the other of two cathedrals and that the three events involving choirs were entitled, in French at least, concerts of sacred or religious music. Branding as sacred or religious is in keeping with French ecclesiastical tradition of the time that concerts held in church buildings were necessarily of music that was in some way associated with the church. But were these four concerts ecclesiastical events, authorized or perhaps even organized by church officials at some level?

Elements absent from the four programs for live audiences suggest that local clergy and church musicians can be eliminated as connected to these events in any way. Before and immediately after the Second World War it was de rigeur in France not only that musical events held in church buildings be of sacred music but also that the performance be held in conjunction with a rite that the whole parish could be expected to attend at that time of day, typically vespers or Benediction of the Blessed Sacrament (Salut). Accordingly, the printed program for a concert held in a church building would indicate the rite-usually to follow the concert or recital-name the presiding priest along with the other leaders of the rite-the titular organist, the parish choir, its director, and possibly a choir organist - and list the antiphons and other texts to be sung as part of the rite. None of the four selected programs for live audiences indicates it was presented in conjunction with a church rite, and none names a member of clergy as connected with the event in any other capacity. This absence strongly suggests that they were neither parish events nor authorized by the parish priest, but that for each concert the building had been taken over by outside event organizers. As a cathedral is the seat of the bishop of the diocese, the unnoted permission of Bishop Lucien-Louis-Claude Martin in the case of Notre Dame of Amiens and Bishop Emmanuel Suhard in the case of Notre Dame of Paris-if their specific permission was granted-may be assumed as having been for use of the building only and not an endorsement of the event. ${ }^{6}$ Therefore, we may also conclude that Duprés engagement for each of the selected live concerts was not by church officials.

One musical work on the Amiens program-César Franck's Pièce heroïque for organ-is in no way sacred and may suggest involvement in this particular program of a coalition of French who called themselves the Groupe Collaboration.7 This alliance of French notables (among them a French cardinal, five members of the Institute of France, two Paris Conservatoire instructors, and many noted writers) was authorized by the occupying powers in January 1941 (Burrin 1996, 380) and was successor to France's 1935-39 Comité

6 According to Philippe Burrin, the stance of the upper ranks of Roman Catholic Church hierarchy in France during the Occupation was that, in exchange for being allowed to conduct its regular worship services and youth meetings with neither interference nor repeated need to seek Nazi authorization to meet, bishops and archbishops cooperated with the Nazi occupiers by agreeing not to speak against the German presence in France or even against Nazi human rights abuses, and accommodated the German presence in other ways that did not interfere with the church's principal activities. It is essential to note that clergy at the parish level did speak out against the occupiers and Nazi policies (Burrin 1996, 217-27).

7 Regarding members and activities of the musical section of the Groupe Collaboration, see Simon 2009, 100-06. 
France-Allemagne. Its members, who "were prone to antidemocratic tendencies or came from antidemocratic backgrounds" (Burrin 1996, 407) were so harshly judgmental of the moral climate in between-the-wars France as to consider France's amalgamation with Nazi Germany in a European state the lesser of two evils. The Groupe Collaboration organized events mainly in Paris but also in the provinces with the help of local supporters. Its music section was headed by composer, conductor, and Paris Conservatoire instructor Max d'Ollone (with whom Dupré cannot be said to have had a close relationship). The Groupe was, moreover, dedicated to supporting Marshal Pétain as head of the French state (i.e., Vichy regime) following the June 1940 armistice with Germany, and supporting Vichy's "National Revolution" that aimed to counter perceived moral degeneration. Franck's Pièce herö̈que for organ could very well have been programmed to honour Marshal Pétain, who, for all French of the generation alive during the First World War, was a national symbol of heroism; for Vichy government supporters, this memory alone justified the imposition of Pétain as French head of state (Jackson 2001, 123-26). As César Franck's entire oeuvre for organ was canonic to French organ music, the choice of this particular piece suggests a more specific association that would have occurred to Pétain supporters. Therefore, its inclusion in the June 1941 program may indicate involvement of the Groupe Collaboration in the organization of the event.

Indicative of the principal backing for all the live concerts is that they featured German musicians on the program or, in the case of Dupré's August 1944 recital, as performers of recitals in the same series (see figure 3). The cultural sections of the Nazi Propaganda Department (Propaganda-Abteilung) in France and the German ambassador to the military government in France organized a stream of visiting German troupes and artists to perform on French soil during the Occupation (Dunan 1951, 29-30; Burrin 1996, 297, 347). The intentions behind musical events ranged from demonstration of fruitful collaboration between German and French musicians to display of German cultural superiority. ${ }^{8}$ For these purposes, the ambassador, long-time francophile Commander Otto Abetz, created in summer 1940 a German Institute that he generously funded as a separate arm of the embassy. In July 1942 Abetz managed to have responsibility for presenting German artists taken away from the Propaganda Department and assigned exclusively to the institute, a change that became effective in November (Dunan 1951, 30; Burrin 1996, 90-92; Simon 2009, 90). Wehrmacht officer and peacetime musicologist Dr. Fritz Piersig was the Propaganda Department's special leader (Sonderführer) for musical activities until he took up a parallel position at the German Institute in autumn 1942 (Kater 2000, 18; Chimènes 2001, 93n10); therefore, it may have been Piersig who

8 As Manuela Schwartz has summarized, the principal aims of the German Propaganda Department (Propaganda-Abteilung) in France and of the German Embassy to the military government in France were to establish on French soil the superiority of German culture so as to justify Germany's political hegemony and break down the psychological barrier to subduing French cultural pride (Schwartz 2001, 89-91). 


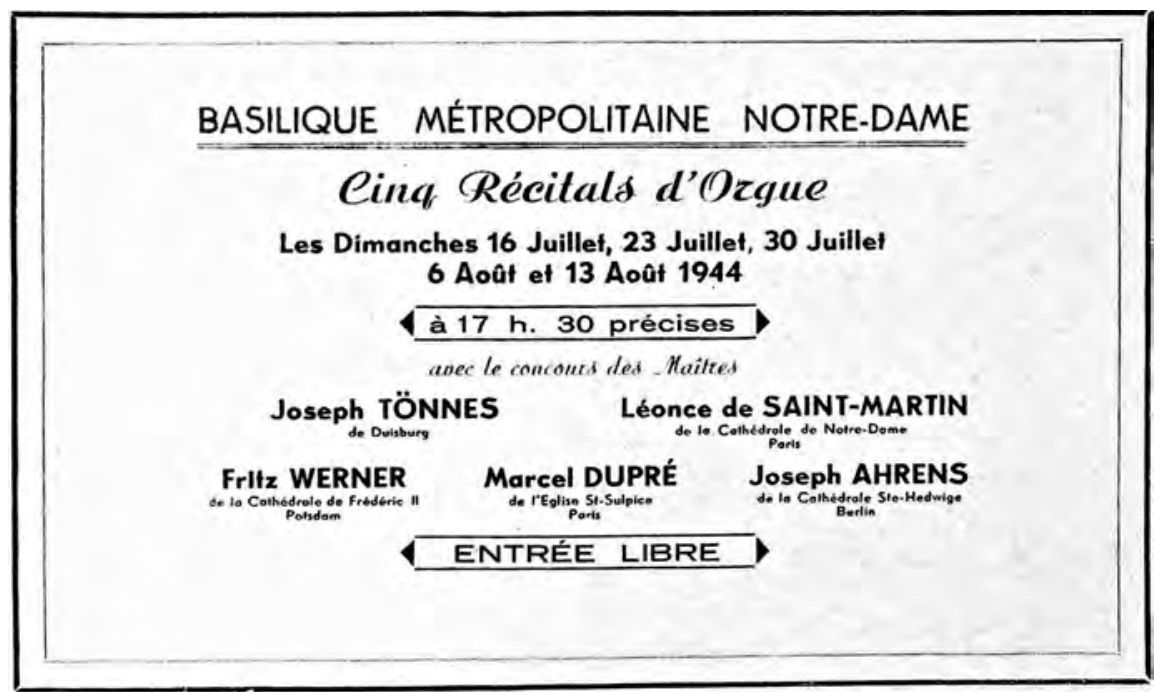

Figure 3. Handbill advertising the series for which Dupré performed his 13 August 1944 solo recital. Bibliothèque national de France, Marcel Dupré Papers, Vma 2803, boîte 6 , unnumbered. Used by permission.

engaged, or directed his staff to engage, Dupré for any or all of the four live concerts under consideration.

Both the military government's Propaganda Department and the embassy's German Institute were headquartered in Paris but operated branches in all the regions of France that were under Nazi control. Hypothetically, then, planning of the June 1941 Amiens concert was initiated and executed by personnel in a northern branch of one of these Nazi organizations. But the visits to Paris of the Bremen Cathedral Choir (December 1941) and the Vienna Boys' Choir (March 1942), and organists Joseph Ahrens from Berlin and Joseph Tönnes from Duisberg (July-August 1944) were likely funded by Ambassador Abetz's generous budget for the German Institute. ${ }^{9}$ Of a different nature-likely an ad hoc group - the "choir of German soldiers and Red Cross ladies" (June 1941 Amiens concert) could have been organized with the assistance of either Ambassador Abetz or a German military commander in the region of Normandy. That these men and women were capable of forming a choir suggests they were all former members of the Hitler Youth, for whom music was a prime subject in their training to serve the Führer (Kater 1999, 135-41).

The second clue that the selected live events were organized by either the Propaganda Department or the German Institute is their programming. As shown in table 2, they contained a preponderance of music by German and

9 The third German organist in the summer 1944 organ recital series, First World War veteran Fritz Werner, was then resident in Paris. In autumn 1942, after he had become Fritz Piersig's replacement as special leader of the music section of the German Propaganda Department, Werner's principal responsibility would have been censorship of concert programs to ensure Nazi-approved political correctness in programming choices. 
Austrian composers in keeping with Nazi-approved political correctness in the arts. The program for the June 1941 musikalisches Feierstunde (musical celebration), as it was entitled on the German-language program page, included an even more explicit kind of cultural chauvinism: the choir of soldiers and Red Cross ladies performed three German nationalistic songs with music composed by Nazi-party members Heinrich Spitta ${ }^{10}$ and Georg Blumensaat. ${ }^{11}$ All three were likely very familiar to the German military in the audience, for songs such as these were basic to the training of the Hitler Youth. For the benefit of French audience members, the printed program gave translations of two of the titles (perhaps as the result of a simple error, the title of the first song by Spitta is missing from the French version of the program); they did not, however, give space to the song texts.

The popularity in Nazi Germany of the first song, Spitta's "Vaterland, heilig Land," is vouched for by the many different musical arrangements by the composer in which it appeared. Its words by Alexander Schröder pledge to the holy Fatherland solidarity and steadfastness, whatever the dangers.

Heilig Vaterland! In Gefahren

deine Söhne um dich scharen.

Von Gefahr umringt, heilig Vaterland,

alle stehen wir Hand in Hand.

Bei den Sternen steht, was wir schwören.

Der die Sterne lenkt, wird uns hören.

Eh' der Fremde dir deine Kronen raubt,

Deutschland, fallen wir Haupt bei Haupt.

Heilig Vaterland, heb zur Stunde

kühn dein Angesicht in die Runde

Sieh uns all entbrannt, Sohn bei Söhnen stehen.

Du sollst bleiben, Land, wir vergehn. ${ }^{12}$ (Rudolph Alexander Schröder)

(Holy Fatherland! Amid dangers your sons rally together. With danger surrounded, holy Fatherland, all stand hand-in-hand.

Standing near the stars, that which we swear. He who guides the stars, will hear us. Before the stranger robs you of your crowns, Germany; we die one by one.

Holy Fatherland, when the hour comes boldly raise your face and look around. See us all impassioned, son by sons standing. You must stay, Land, we must die.)

10 Musicologist Heinrich Spitta (1902-72) was nephew to the Bach scholar Philipp Spitta. Regarding the roots of Heinrich Spitta's Nazism and his involvement with the Hitler Youth, see Kater 1999, 167-68; and Die Musik in Geschichte und Gegenwart, 2d ed., s.v. "Spitta, Heinrich," 15:1195; Kater 2004, 33 .

11 Composer Georg Blumensaat (1901-45) was a student of Paul Hindemith who provided the music for the 1940 German documentary film Unsere Jungen. Ein Film der nationalpolitschen Erziehungsanstalten (Our boys: A film [commissioned] by the national-political educational institutions), a twenty-minute film directed by Johannes Häußler (Berlin, 1940). See IMDb, http://www.imdb.com/ name/nm4714192/.

12 All song text translations are by the author. 


\section{Table 2. Repertoire from five Marcel Dupré programs}

\begin{tabular}{|c|c|c|c|c|c|}
\hline $\begin{array}{l}\text { Date, time, and title on } \\
\text { printed program }\end{array}$ & $\begin{array}{c}1 \text { June } 1941 \text { (Sunday) 8:00 } \\
\text { p.m. } \\
\text { Concert de Musique Sacrée } \\
\text { Musikalische Feierstunde }\end{array}$ & $\begin{array}{c}6 \text { December } 1941 \text { (Saturday) } \\
\text { 6:00 p.m. } \\
\text { Concert de Musique } \\
\text { Religieuse }\end{array}$ & $\begin{array}{c}15 \text { January } 1942 \text { (Thursday) } \\
\text { 10:15 a.m. }\end{array}$ & $\begin{array}{c}12 \text { March } 1942 \text { (Thursday) } \\
\text { 6:30 p.m. } \\
\text { Concert de Musique } \\
\text { Religieuse }\end{array}$ & $\begin{array}{l}13 \text { August } 1944 \text { (Sunday) } \\
\text { 5:30 p.m. } \\
\text { Quatrième Récital d'Orgue }\end{array}$ \\
\hline Program repertoire & $\begin{array}{l}\text { - Bach, Fugue in C Major } \\
\text { [BWV ? ed. Dupré] } \\
\text { - Reger, Benedictus (in } \\
\text { D-flat, from op. 59) } \\
\text { - Franck: Pièce heroïque } \\
\text { - Three German patriotic } \\
\text { poems set to music by } \\
\text { composers H. Spitta and } \\
\text { G. Blumensaat } \\
\text { - Improvisation on the } \\
\text { Blumensaat melody } \\
\text { - Bach, "Mon âme } \\
\text { croyante" /Mein glaübi- } \\
\text { ges Herze" from Also hat } \\
\text { Gott (BWV 68) } \\
\text { - Bach, Toccata and Fugue } \\
\text { in D Minor (BWV 565, ed. } \\
\text { Dupré) }\end{array}$ & $\begin{array}{l}\text { Three pairings of canonic } \\
\text { organ and choral works } \\
\text { that are usually by same } \\
\text { German or Austrian com- } \\
\text { poser, including } \\
\text { - Mozart Fantasy and } \\
\text { Fugue in F Minor (ed. } \\
\text { Dupré) } \\
\text { - Reger, Introduction and } \\
\text { Passacaglia in D Minor } \\
\text { (Woo). } \\
\text { - Bach, Prelude and Fugue } \\
\text { in G Major (BWV 541? } \\
\text { ed. Dupré). See also } \\
\text { figure 2. }\end{array}$ & $\begin{array}{l}\text { - Bach, Prelude and Fugue } \\
\text { in A Minor (BWV 543? } \\
\text { ed. Dupré) } \\
\text { - Schumann, Canon in B } \\
\text { Minor (ed. Dupré) } \\
\text { - Brahms, Est ist ein Rose } \\
\text { (op. 122, no. 8) } \\
\text { - Dupré, Scherzo (op. 16) }\end{array}$ & $\begin{array}{l}\text { - Bach, Prelude and Fugue } \\
\text { in A Minor (BWV 543? } \\
\text { ed. Dupré) } \\
\text { - Choral works by Pales- } \\
\text { trina, di Lasso, Victoria, } \\
\text { Jacobus Gallus, Bach, } \\
\text { Handel, Mozart, and } \\
\text { Schubert } \\
\text { - Handel, Allegro from } \\
\text { Organ Concerto no. } 10 \\
\text { (arr. Dupré) }\end{array}$ & $\begin{array}{l}\text { - Bach, Fantasy and Fugue } \\
\text { in G Minor (BWV 542, ed. } \\
\text { Dupré) } \\
\text { - Mozart, Fantasy No. } 2 \text { in } \\
\text { F Minor (ed. Dupré) } \\
\text { - Franck, Grande pièce } \\
\text { symphonique } \\
\text { - Dupré, Symphonie Pas- } \\
\text { sion: III } \\
\text { - Improvisation (on the } \\
\text { theme Frederick the } \\
\text { Great of Potsdam gave to } \\
\text { J.S. Bach) }\end{array}$ \\
\hline
\end{tabular}



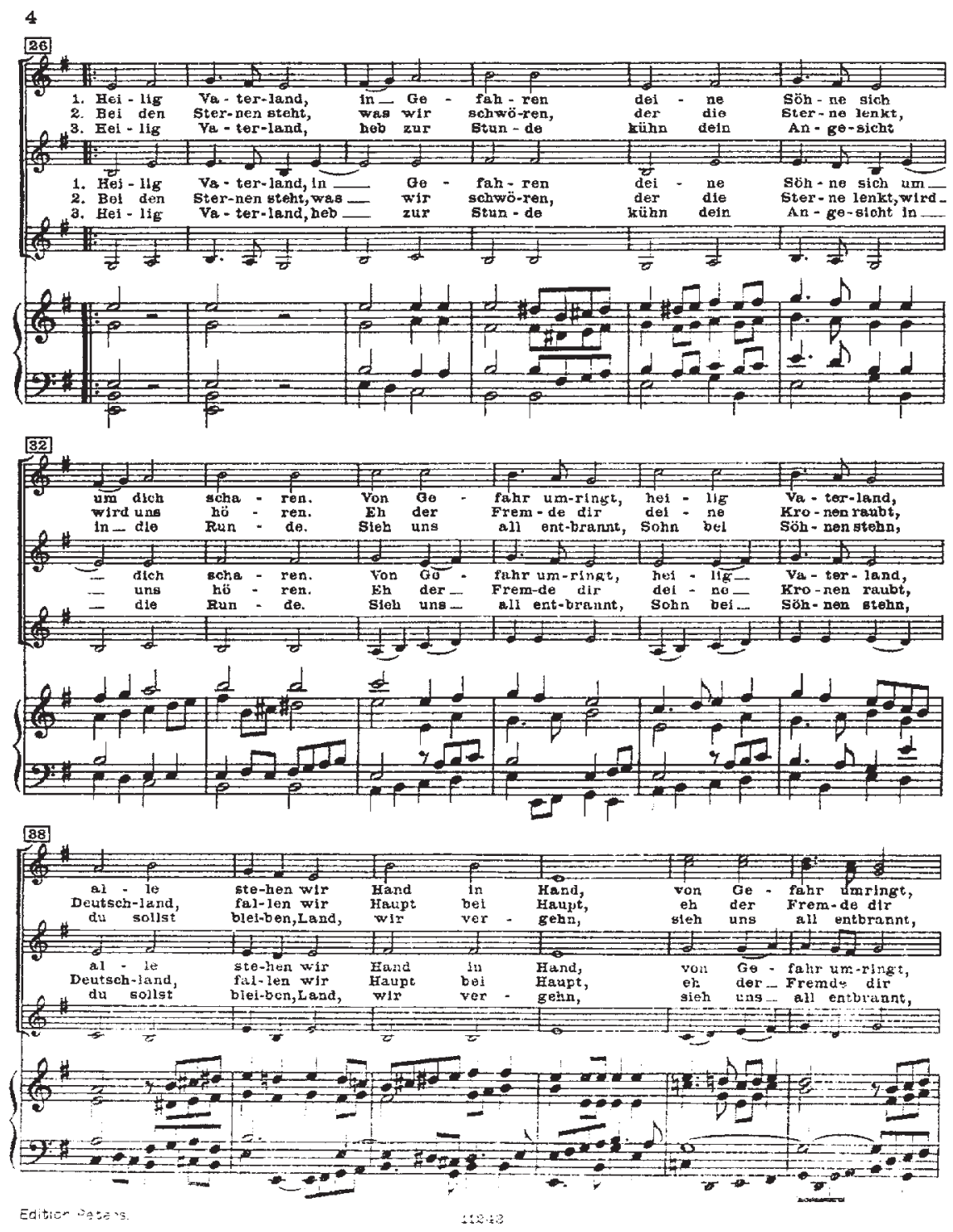

Figure 4. Excerpt from Heilig Vaterland: Hymne aus der Kantate "Deutsches Bekenntnis," op. $31^{\text {b }}$ by Heinrich Spitta. Copyright (C) 1934. Used by permission of C.F. Peters Corporation. All rights reserved. 
Figure 4 shows a page from the musical setting for one or more voices with keyboard accompaniment. ${ }^{13}$ Spitta's tune is in a pseudo-sacred style, reminiscent of plainchant in its modality but solidly German-chorale-like in its metre and form. Words and tune together play into the notion that Nazi ideology should eventually become a substitute for religion (Kater 1999, 170).

Another of the three patriotic poems, "Deutschland, heiliges Wort," refers specifically to Germany and draws heavily upon the vocabulary of Christian hymns. It reads:

Deutschland, heiliges Wort, du voll Unendlichkeit!

Über die Zeiten fort seist du gebenedeit!

Heilig sind deine Seen, heilig dein Wald und der

Kranz deiner stillen Höhn bis an das grüne Meer!

Eberhard Wolfang Möller.

(Germany, holy word, filled with infinity! May you be forever blessed!

Holy are your lakes, holy are your forests, and [holy is] the wreath of your silent heights, down to the green sea!)

In the anthology Lied über Deutschland, this text is set to a melody in the style of a German military march (see figure 5). Thus paired, text and tune are easily imagined as another mainstay in the training of the Hitler Youth.

The poem "Nichts kann uns rauben" is more secular in its vocabulary:

Nichts kann uns rauben

Liebe und Glauben

zu unserm Land;

es zu erhalten

und zu gestalten

sind wir gesandt.

Mögen wir sterben,

unseren Erben

gilt dann die Pflicht,

es zu erhalten

und zu gestalte

-Deutschland stirbt nicht!

Karl Bröger (1886-1944)

(Nothing can rob us of our love and faith for our country; we are sent to preserve and shape it. Should we die, then our heirs accept as [their] duty to preserve and shape it-Germany shall not perish!)

Spitta's tune for "Nichts kann uns rauben," which, like "Vaterland, heilig Land" was published in multiple musical arrangements, features the metre and rhythms of a militant national anthem. ${ }^{14}$ Together, the three German nationalistic songs mark the June 1941 program as a Nazi cultural propaganda event,

13 Perhaps this was the arrangement actually performed in Amiens on 1 June 1941. The choir of soldiers and Red Cross ladies possibly included someone who took the keyboard part.

14 Arrangements of Spitta's "Nichts kann uns rauben" and Blumensaat's "Deutschland, heiliges Wort" may be heard on Deutsche National-Hymnen, CD 4442 (Munich: FZ-Verlag, 1999). 


\section{Vom Glaubm}
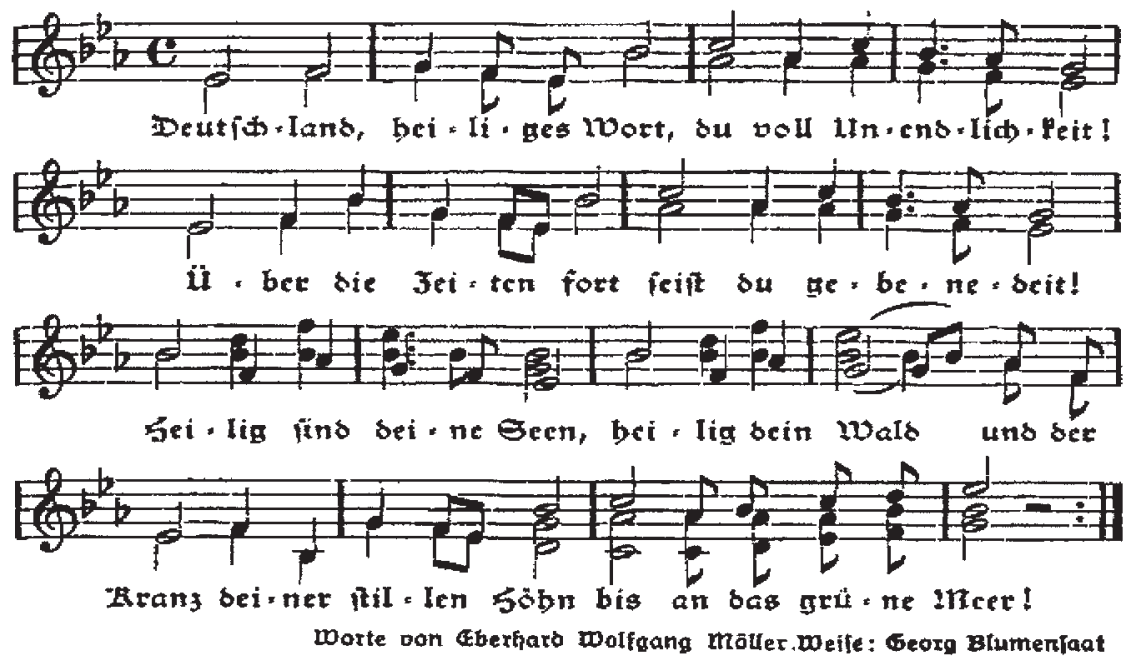

Mit Genefmigung bes Georg Kallmeyer=Derlages, Dolfenbüttel.

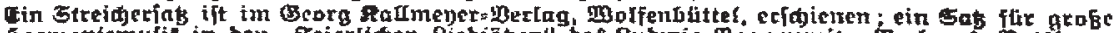

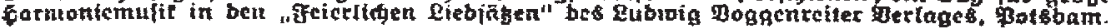

Figure 5. "Deutschland, heiliges Wort" by Georg Blumensaat, from Lied über Deutschland, ed. Georg Blumensaat (Potsdam: L. Voggenreiter, 1936), 27. Copyright (music) by Möseler Verlag, Wolfenbüttel (Kallmeyer Verlag). Used by permission.

whether organized by the military government's Propaganda Department or the embassy's German Institute.

The use of a large organ for solo organ repertoire in each of three choral concerts had Nazi propaganda significance too. In Germany, where concert hall organs were more common than in France, the Nazi regime had, for the past six years, been making political use of organs in public ceremonies to salute Hitler and his regime-indeed, to symbolize the power of Hitler (Kater 1999, 173-74). Moreover, organ works by Bach, the most frequently included composer in the five selected programs, suited Nazi purposes in a symbolic way, beyond the fact of Bach as ethnically German: by 1938, Nazi-party event organizers had adopted some of the free organ music of Bach as suitably festive for use in national ceremonies (Kater 1999, 174; see Thacker 2006, 30-31).

As mentioned earlier, one of the aims of Nazi cultural propaganda in France was to enable joint performances by German and French musicians. Of the 
many organists who remained in France during the occupation, why was Dupré engaged for the four live concerts? He debuted in Germany in 1928 and fulfilled one return engagement in 1929, but was not particularly well known there prior to the Second World War. Rather, he would have been engaged on the strength of his domestic reputation as France's most distinguished concert organist. He may have first come to the military government's attention as a result of a summer 1940 incident in which German officers visited his home in the Paris suburb of Meudon with the intention of planning the instalment of anti-aircraft missiles on the roof of an attached structure, which happened to be Dupré's organ hall. This plan was discarded on the decision of a German officer who seemed to recognize the musical importance of the work Dupré carried out in the hall (Dupré 1975, 107). ${ }^{15}$ His politics must also have been regarded by personnel in the military government's cultural branches as, at the very least, neutral; there are two pieces of evidence that this was so. First, according to a report by a military government bureaucrat, in 1941 Dupré's name was on the provisional list of French artists chosen by the German Institute to participate in a trip to make contact with French artists resident in Germany, a trip that never took place, however (cited in Burin 1996, 349). Second, another military government report on musical affairs gives an update on the question of a new director for the Paris Conservatory near the start of 1941. The report states that two of the applicants-Claude Delvincourt and Marcel Dupré-"are equally acceptable in both their politics and their attitude towards German art" (Paris National Archives, AJ/40/1001, folder 7, cited in Simon 2009, 94). The fact that Delvincourt would eventually be hailed as a hero of the French Resistance movement demonstrates that it is difficult to draw from this statement anything specific regarding Dupré's political loyalties.

Why, then, did Dupré accept concert engagements from the German military government? There is no evidence he supported the notion of cultural integration between France and Germany. Nor does it stand to reason that he accepted every last concert engagement out of pure opportunism, for he was already independently wealthy. ${ }^{16}$ I will argue, rather, that performing alongside German musicians and performing Germanic music juxtaposed with French music afforded Dupré his own propaganda platform.

Dupré, as well as being proud of achievements in French music history, had a battle to fight among French organists. His post-romantic aesthetic position made him resentful, even fearful, of a separate stream of organ playing that

15 According to French operatic soprano Germaine Lubin, the sympathetic German army officer who made this decision was her friend Captain Joachim Lange, whom she brought to Meudon to hear the organ because Dupré had appealed to her to use her connections to prevent the installation of guns on the roof of his organ hall (Casanova 1974, 181). Corroborating evidence of Lubin's and Lange's involvement is lacking other than the fact that, in an essay concerning the musical significance of Meudon, French musicologist Christiane Colleney treats as fact their involvement in the happy outcome of the visits by German army officers, but does not cite her source or include Casanova's book in the list of works cited (Colleney 1987, 20, 79).

16 Widor's advice to Dupré in 1922: "Try to make enough money there [in America] to be independent" (quoted in Murray 1985, 89). By 1940, Dupré had made eight North American tours. Regarding other sources of Dupré's affluence, see Murray 1985, 115n3. 
emerged in Paris in tandem with Germany's anti-romantic, organ-reform movement (known, since about 1930, as the Orgelbewegung). ${ }^{17}$ The Paris association Les Amis de l'Orgue was formed in 1927 to encourage such activities as concert performances of complete organ masses from the French baroque, new organ compositions deriving from a neoclassic aesthetic, and experiments towards an organ design they called neoclassic. Alongside emerged the figure of a French organist who was an interpreter but not necessarily a composer. These trends were reversals of style traits of the French organ school in which Dupré grew up and that he believed was now poised to evolve a futuristic organ design and compositional style; neoclassicism was, therefore, anathema to him. Dupré needed to concertize during the war, if only to hold his ground against his neoclassic rivals' bid to win audiences to their own wartime concert series. ${ }^{18}$ Meanwhile, performing concerts that both French citizens and German military personnel in France could be expected to attend provided opportunity to confront head-on Germany's purported musical supremacy. In these concerts, Dupré displayed the heritage of the French organ school on four historical fronts that were also his points of disagreement with the French neoclassic stream of organ playing.

First, in his role as teacher of organ interpretation at arguably the most famous music conservatory in the world, Dupré regarded himself as curator of the principal repertoires of organ music by Germanic composers. For Dupré, as for Widor, Bach was a universal composer whose organ works were performed most intelligently by the French school descended from the Belgian organist Nicholas Lemmens (1823-81). He was proud of his new performing edition of the organ works of J.S. Bach, a twenty-year labour of love for the benefit of students that appeared in print during 1938-41. He could also take personal pride in the other repertoire by Germanic composers he performed in the five programs: he had, by then, made arrangements for solo organ of many of Handel's organ concerti (published 1937-42) and had in progress editions of Mozart's Fantasias Nos. 1 and 2 for organ and the complete organ works of Schumann. ${ }^{19}$ The works by Reger (June 1942 and December 1941) and Brahms (January 1942) were not part of Dupré's standard repertoire, but this was true of much repertoire he performed in concert on the rare occasion: as his biographer pointed out, he frequently honoured a foreign host by preparing-just for that engagement-performance of a work by one of their own (Murray 1985, $184 \mathrm{n} 4)$.

17 For a viewpoint on the politics of the Orgelbewegung in Germany of the 1930s, see Kater 1999, $171-72$.

18 Occupation-period lecture-recitals by organist André Marchal and musicologist Norbert Dufourcq, members of Les Amis de l'Orgue and strong proponents of the neoclassic organ, are referred to in Englert-Marchal 1985, 41-42.

19 Dupré's editions of Mozart's two F-minor fantasias for organ, the Schuman Canon in B Minor and Schumann's Fugue on the Name of Bach were published in 1942, and his complete Schumann edition in 1949. His Mendelssohn edition appeared in 1948 and may also have been in progress during the war. Though Dupré adhered to the ban on public performance of Mendelssohn, he continued to teach Mendelssohn's organ works during the Occupation. 
Second, two of the live concerts gave Dupré opportunity to demonstrate French excellence in extemporizing in any standard musical form upon a melody submitted immediately prior to the time for improvisation. To improvise on "Deutschland, Heiliges Wort"- a tune he could be assumed never to have heard until the moment of its singing in the Amiens concert-would display beyond any doubt his mastery of this art. Most often, he improvised on a brief, written theme, original or not, handed to him after the last set piece of a recital. As we know from Jeanne Demessieux's diary, at his August 1944 recital this submission was the famous theme that Frederick the Great gave to J.S. Bach (Demessieux 2009, 175). It was possibly proposed by another participant in the recital series, Fritz Werner, who was billed as titular organist of Frederick II Cathedral in Potsdam, but was then working as music censor for the Propaganda Department in Paris. In the introduction to his treatise on organ improvisation, Dupré had already cited Bach's Musical Offering as the most striking instance of improvised creativity ever known (Dupré 1925, n.p.). Accepting the same challenge in a public recital as part of a French-German series, he would have delighted in fashioning an original composition on a theme for which there existed already many elaborations by a universally admired master. In short, though the melody for each improvisation in these concerts was Germanic, and one was entitled "Allemagne, nom sacré," Dupré would have regarded his improvisations as superior French cultural products that challenged German musical hegemony.

Third, there was opportunity in the solo organ recital and in his RadioParis programs to showcase examples of originality in French organ music. In his repertoire for his August 1944 recital he juxtaposed fantasias by Bach and Mozart with two examples of a genre invented in France, the organ symphony. Franck's Grande pièce symphonique, op. 17, an extended work without breaks between movements, was solidified historically as a new genre when it was followed by Widor's ten, and Vierne's six, multi-movement organ symphonies. Dupré next did them one better when he became the first ever to improvise in concert a thirty-minute, multi-movement organ work modelled after existing composed organ symphonies, which he later set down on paper as his Symphonie-Passion. ${ }^{20}$ By performing one of its four movements following the grand symphonic work by Franck, he juxtaposed two milestones in French organ composition.

Moreover, by 1942 Dupré was himself the composer of seventeen published organ works, over half of them more suited to concert than liturgical use and on a par with French chamber and symphonic repertoire. The majority of these compositions were in an original style that stretched the boundaries of what was thought playable on the organ during the first half of the twentieth century. His recital for radio broadcast detailed in table 2 (January 1942) was largely of German repertoire, as Radio-Paris probably required, but it also allowed him opportunity to conclude with his own Scherzo, op. 16, composed in about

20 Dupré achieved this in a concert in Philadelphia in 1921 (Steed 1999, 31; Murray 1985, 81-82). The resulting Symphonie-Passion, op. 23 was first published by Leduc in 1924 . 
1918. A dazzling, chromatic moto perpetuo for manuals and pedal, it surpassed everything by Widor in its virtuosic demands, making it unplayable by anyone other than Dupré in 1918. Over five-and-a-half minutes long, it requires continuous left-hand sixteenth-note motion at the speed of dotted quarter note $=72$, frequent manual changes by one or the other hand, and execution of a prominent pedal line amid frequent adjustments to the swell box by the right foot.

Fourth, examples of French architecture and engineering superior to their period-equivalents in Europe were on display at the live events. The construction of Notre Dame Cathedral in Paris began in the twelfth century; Notre Dame in Amiens, the largest cathedral in all of France, followed in the thirteenth century and set, yet again, a new standard for architectural grandeur. Equally venerable are these cathedrals' organ traditions. There has been an organ in the gallery of Notre Dame of Paris since 1403 (Wright 1989, 146). Amiens Cathedral has had a series of increasingly large gallery organs since 1429. ${ }^{21}$ When Dupré, while serving as substitute organist for Louis Vierne at Notre Dame in Paris, had the honour of improvising the national victory Te Deum in November 1918, he was echoing victory Te Deums heard in that Paris building from centuries before.

More importantly, both cathedrals' gallery organs as they existed in the 1940 s were designed and engineered by the nineteenth-century French genius Aristide Cavaillé-Coll, whom Dupré, his forebears, and his disciples idolized. ${ }^{22}$ Whereas at the start of the Industrial Revolution France lagged behind Britain in new technological developments, in the nineteenth century, and when it came to solving organ design issues that arose out of the romantic-music aesthetic, French achievements-those of Cavaillé-Coll in particular-attracted the most international attention (Douglass 1999, 144-45, 17-18, 32, 96). When he rebuilt and enlarged the eighteenth-century five-manual organ of St. Sulpice (January 1942 program), a feat that required solving several taxing engineering problems, French government inspectors of the instrument were so proud of this accomplishment that they entered the construction drawings in that same year's London World Exhibition (Ochse 1994, 75). The magnificence of French medieval architecture and of Cavaillé-Coll's grand organs were further reasons Dupré would take an audacious patriotic pride in playing concerts apparently organized and funded by the Nazi Propaganda Department or the German Institute.

By considering the music, venues, and instruments for these concerts, we have noted repeatedly that Dupré's celebrations of French organ culture were retrospective rather than oriented towards the present. During the Occupation he did not perform his latest, most groundbreaking compositions or invite the general public to hear the technologically innovative organ at his home in Meudon. His veneration for the glorious history of French organ playing

21 http://www.musiqueorguequebec.ca/orgues/france/amiensnd.html.

22 Dupré's father, Albert Dupré, concluded a lengthy address to the Rouen Academy of Science and Arts concerning Cavaillé-Coll's organ-building genius with the words, "Just as Italy takes pride in having Stradivarius, France can be proud to have Cavaillé-Coll” (A. Dupré 1919, 36). 
caused him-and French citizens, no doubt-to disassociate his public concertizing from current political reality and even disassociate it from the Nazi organizers of some concerts. He dared this because of his confidence that the historical organ culture he represented would inspire French national pride such as could see its citizens through another war-inflicted disaster.

There is evidence that his Occupation-period concertizing achieved this goal. According to Dupré disciple Jeanne Demessieux, the German organist's recital she attended at Notre Dame in Paris on 6 August 1944 was dreadful, whereas a week later Dupré's was a stunning triumph. Her diary notes an estimated attendance of 6,500 people that Sunday evening. The recital over and electrified fans spilling into the square through the cathedral's main gate, when Dupré attempted to exit by another gate the entire mob that filled the cathedral square dashed towards him, their numbers such that the police on hand gave up trying to control the crowd (Demessieux 2009, 174-75). This occurred ten weeks after D-Day and ultimately proved to be less than two weeks before the official Liberation of Paris on 26 August 1944. If Demessieux was not exaggerating, on the evening of 13 August Dupré was treated as a French national hero. He could be proud that though not a representative of the rising French neoclassic school, he enjoyed French citizens' highest confidence in the excellence of his organ-playing.

\section{Part 2: Collaboration, Accommodation, and the ÉPURATION}

At the Liberation of France, the interest of the new government and the general public was not in celebrating their country's untarnished cultural glory but in apportioning blame on each other for its political shame, during a period known as the épuration (purge) of collaborators. Even allowing for a historically contingent definition that applies to the Second World War, the meaning of the word collaborator is slippery. It applies first and foremost to those European citizens who used their political, military, or economic power, or divulged intelligence, in ways that abetted the Nazi abrogation of persons' lives, freedoms, and life necessities. The word also applies to those French citizens who favoured entente-harmony, understanding-with Nazi Germany, and those who, emboldened by the Vichy regime, advocated their own authoritarian, anti-republican values in the press, the arts, and education-most notably members of the Groupe Collaboration. The concept of collaboration applies, foremost, to those whose actions had political implications (Burrin 1996, 2).

To have accepted favours from, the patronage of, or done favours for the occupiers-as Dupré at first glance appears to have-or to have mingled with Germans in either official cultural or social events, though without political intent (there is no evidence that Dupré did this) are what Burrin has termed "accommodation" of the occupiers. By making this distinction, Burrin aimed not to excuse acts of accommodation but to demonstrate that, in addition to the common motive of self-survival, accommodation resulted, at the time, not from disloyalty to republican principles but from "a partially confused image 
of the occupier, an opaque future, [and] disagreement as to the correct definition of the national interest." (Burrin 1996, viii). Dupré, as we have seen, had his own understanding of the national interest when it came to the art of the organ.

Another historian, Jackson, believes that the notion of collaboration needs to be just as inclusive as resistance (Jackson 2001, 242-43). For instance, if a musician who refused to perform for Radio-Paris is said to have resistedmembers of the Front national de la musique banned this activity, among others, and counted themselves as resistors (Simon 2009, 336-38)-one who performed for Radio-Paris had collaborated. From this point of view, almost every French musician in Paris during the Occupation collaborated at least once (according to Yannick Simon, French musicians who did not perform for Radio-Paris were rare [Simon 2009, 97]), and even cooperative acts carried out to prevent reprisals on others or, as in Dupré's case, to evidence a personal brand of French patriotism, equalled collaboration with the enemy, not mere accommodation. Given these different verdicts, we must ultimately agree with Sprout, who regards as a lingering misconception the notion that today we can make "definitive moral judgments" about French musicians' wartime careers (Sprout 2013).

It was another matter how post-Liberation purge committees chose to define and to punish collaboration by musicians. Some musicians who had performed for Radio-Paris were called up before one or the other purge committee concerned with the performing arts. At one extreme, composer-pianist Jean Hubeau is documented as having performed for Radio-Paris 189 times, for total remuneration of 269,000 francs. At first, he had simply to answer for this before the Commission d'épuration du spectacle. Later, for the same actions, he was called up by a new body, the Comité national d'épuration des gens de lettres, auteurs et compositeurs, and there sentenced to four months' suspension from all professional activity (Simon 2009, 359). At the other extreme, it may be true that singer Jeanine Micheau, for a limited amount of work with Radio-Paris, was suspended from all professional activity for a year (Casanova 1974, 206). ${ }^{23}$ Scapegoating of individuals was common during the purge.

Other musical activities that came under scrutiny were performance with German musicians in France and concert appearances in Germany. The pianist Alfred Cortot, for performing in France in the company of German musicians (e.g., during a week of festivities in Paris celebrating Hitler's favourite sculptor, Arno Breker) and in events organized by the German Propaganda Department (e.g., the December 1941 Mozart week in Paris), was sentenced to a one-year suspension of all professional activity by the Comité national d'épuration des professions d'artistes dramatique, lyriques et de musiciens

23 Micheau's punishment may also have been for taking a role in a French-language performance of Strauss's Ariadne auf Naxos (Casanova 1974, 206). I suggest may because others who performed music by Nazi-approved German composers, such as pianist Nelly Audier (Simon 2009, 114, 139), went unnoticed (see 358). 
exécutants (Chimènes 2001, 45, 48). ${ }^{24}$ Additional punishments might have been heaped upon Cortot, but were not: for serving in the collaborationist Vichy government, for accepting invitations to perform extensively in Germanic countries during the occupation of France, and for rubbing elbows with Germans at social events in Paris and Vichy-all the while speaking in favour of increasing German-French artistic cooperation. Punishments contemplated for these activities were commuted or suspended when it was argued that some of his actions as a Vichy government official had been for the benefit of French musicians oppressed by the Nazis $(48-49){ }^{25}$

Generally speaking, sanctions and punishments of French musicians following the Liberation did not affect their careers or posthumous reputations very much at all. The notable exception was treatment of the internationally acclaimed Paris Opera soprano Germaine Lubin (1890-1979), a musician whom Dupré counted as a family friend (Dupré 1975, 110). ${ }^{26} \mathrm{Her}$ at-home, pre-war reputation as the greatest operatic soprano France had ever produced paralleled Dupré's stature among organists. Having resumed near the start of the Occupation her position with the Paris Opera (where, unfortunately, she had a following among Nazi officers as the result of her prior successes in Germany), for performing during the Arno Breker festival (which she claimed was only for the sake of brokering a deal to have the Jewish pianist Maurice Franck freed from prison [Casanova 1974, 182-83]), and for performing with German musicians in France (specifically, the Berlin Opera under Herbert van Karajan in its 1941 visit to Paris), she was subjected to extreme denunciation and severe punishment. ${ }^{27}$ After a series of trials heard by magistrates and juries, Lubin was fined the totality of her financial assets (later reduced to one million francs), banished from France for twenty years (soon reduced to banishment only from the region of her chateau), banned from singing in France and certain neighbouring countries for life ("national disgrace," later reduced to five years), and prohibited from ever again holding a titular position in France-as performer or teacher (Casanova 1974, 220-21; Rasponi 1982, 92).

24 French soprano Anne-Marie Bernard, who participated in the 1941 Amiens concert by singing "Mon âme croyante" / "Mein gläubiges Herze" from Bach's cantata Also hat Gott die Welt geliebt, BWV 68 , is not known to have come to the attention of a purge committee.

25 During the Occupation, public performance of classic German repertoire by French musicians was not necessarily controversial. One latter-day commentator raised an eyebrow, though, at participation by the celebrated French soprano Irène Joachim in a Max Reger anniversary concert in May 1941 (Burrin 1996, 347). More surprising is Joachim's performance in a February 1942 Paris concert of new music by contemporary German composers who had been selected by the German Institute (Simon 2009, 114). Joachim's general reputation remained unsullied because she meanwhile refused all invitations to perform either in Germany or with German musicians visiting France. According to Brigitte Massin, she did so while pointing out to the occupiers that her grandfather was the great Hungarian-born violinist of Jewish background Joseph Joachim (Massin 1999, 258-59).

26 Regarding Dupré and Lubin, see also note 13 of this article. Lubin is said to have solicited from Dupré a letter testifying to the aid she gave him in preventing the German military from installing anti-aircraft guns on the roof of his organ hall, a letter that apparently was not provided (Casanova 1974, 180-81, 211-12).

27 It is not true, as Chimènes states, that Lubin performed in Germany during the Second World War (Chimènes 2001,31). Rather, she sang in Berlin and Bayreuth during the eighteen months prior to France's declaration of war on Germany (Casanova 1974, 135-56). 
In short, sanctions and punishments for musicians who worked with Germans during the Occupation were applied haphazardly, were often mere tokens of disapproval (particularly when compared to punishments meted out to French journalists and intellectuals who wrote for Nazi-tainted publications), ${ }^{28}$ but potentially could effect life-long damage to a musician's career. In 1940, Dupré, like Lubin, had jealous rivals who resented his position at the top of their profession. His stature as France's most celebrated concert organist had been underscored by bestowal upon him of the ranks of Chevalier (1923) and Officier (1935) of France's Légion d'honneur. In 1948 his rank would be elevated to that of Commandeur de la Légion d'honneur. To have suppressed the true extent and nature of his Second World War concertizing is not an indication that he considered himself guilty of wrongdoing, but that he feared for his reputation.

\section{Part 3: Application to Dupré's Second World War-Period Compositions}

Of what musical significance, then, is this revelation that during the Occupation Dupré accepted invitations to perform in concerts organized as Nazi cultural propaganda, alongside visiting German musicians? As I argued in part 1, the strength of Dupré's veneration for the history of French organ playing caused him to disassociate even these public performances from current political reality, so that he might take advantage of every opportunity to celebrate the French musical heritage, while countering his opponents in the Paris organ wars raging since the 1920s. Understanding the strength of Duprés obsession with the musical past helps bring into perspective a peculiarity of his choices of extra-musical subjects for his Occupation-period compositional projects: curiously, the musical works he composed during the German occupation, works published during 1941-45 as his opp. 37-41, are devoid of references to the war, human suffering and hope for peace. This is unlike his First World War period, during which he composed the cantata De Profundis, op. 17 (1917), and his immediate post-Second World War period, which saw composition of the organ work Paraphrase on the Te Deum, op. 43 (1946) and the cantata La France au Calvaire, op. 49 (ca. 1953); at the premieres of all three, these compositions were understood by the composer, the first audience, and critics as expressing wartime suffering leading to ultimate triumph or redemption.

Instead, Dupré's opp. 37-41 were all rooted in personal concerns. Let us take as an example his Évocation, op. 37, a three-movement organ work completed in 1941 and premiered in Rouen that autumn, which Graham Steed has claimed

28 Whereas journalists whose work was coloured by fascism were punished severely, music composition in cooperation with Nazi Germany was not nearly as reprehensible. For writing music for a film commissioned by the Nazi propaganda department in France, one that stigmatized French Jews and Freemasons, Jean Martinon was condemned to three months' suspension of professional activity by the Commission d'épuration du spectacle (Simon 2009, 359). The Comité national d'épuration des gens de lettres, auteurs et compositeurs did not, however, call up any of the eighteen French composers who wrote one or more film scores for Continental-Films. a German-financed company, during the Occupation (Simon 2009, 363). 
is a musical representation of Dupré's wartime experiences and thoughts of France. The work's genesis was as follows. In July 1941, Dupré told Demessieux he was writing a "symphony" in memory of his father, implying, too, that he intended the work's premiere to take place on the Cavaillé-Coll organ of St. Ouen in his city of birth, Rouen (Demessieux 2009, 85). St. Ouen was where his father was titular organist until his death in 1940. Meanwhile, its gallery organ had been dismantled in 1939 for renovations that, as a result of the onset of war that same year, were only just beginning in 1941. (For the father's memorial service in Rouen in 1940, the gallery organ had, of course, been silent, another motivation for remembering Albert Dupré at the re-inauguration recital.) Both the composition of Évocation and restoration of the St. Ouen organ were completed in time for a late-October 1941 premiere and re-inauguration recital that served also to commemorate the composer's father (Murray 1985, 183). Évocation was published in 1942 as a poème symphonique pour orgue with dedication "À la mémoire d'Albert Dupré, Organiste du grand-orgue de la basilique de $S^{t}$ Ouen de Rouen." The change of genre from symphony to symphonic poem, despite its being a three-movement work, is perhaps an indication of the programmatic rather than abstract nature of Dupré's op. 37.

Furthermore, the French word évocation, when not referring to an invocation (as of spirits or demons), denotes the act of bringing back to mind, or recalling-especially something forgotten-but definitely something from the past. According to Dupré's Rouen friend Canon Robert Delestre, who must certainly have attended the premiere and spoken to Dupré at this time, the work was meant to evoke places in the composer's childhood that formed him musically: the family home in Rouen (with its music room and organ); the magnificent edifice of St. Ouen, its Cavaillé-Coll organ and the organ gallery where, at four years of age, he first met Widor (Delestre 1952, cited in Murray 1985, 183-84).

The problem is that Graham Steed attempted to impose a further meaning on Dupré's op. 37-making it evocative of war and of hope for France's eventual redemption (Steed 1999, 91-94). According to Steed, in a 1966 interview, for which Dupré had time to prepare his remarks, the composer told him that the work was meant to evoke St. Ouen, his first meeting with Widor, the sad circumstances of his father's death, and facets of his father's interests and personality (Steed 1999, 92-93). Steed then suggested to Dupré that certain passages of Évocation were best understood as evoking memories of the outbreak of war in 1914, the disastrous defeat in 1940, "a farewell to the ancient glories of France," "a call to arms," and "a vision of a new France." To this Dupré responded that Steed "has read my inmost thoughts" (Steed 1999, 93). One is left to wonder why the composer should have kept this interpretation hidden until presented with it by another organist. There is, of course, no reason why in 1963 the work should not have evoked for him memories of the Second World War and his Occupation-period hopes for the eventual liberation of his country. Perhaps the reason he latched onto Steed's interpretation was the added sheen this interpretation lent to a work that no one other than Steed was then performing. 
But as for the question of what Dupré had in mind when he composed and performed Évocation during the Second World War, knowing both his preoccupation with the musical past and the meaning of the word évocation as a recalling from the past, it seems very unlikely that the composer originally intended to evoke wartime suffering and hopes of future national redemption. ${ }^{29}$ The consoling funeral march near the end of the first movement was for Albert Dupré, not for France. Passages in the same movement that sound cataclysmic, and final movement passages that are martial or victorious, evoke the same moods as passages from his Symphony in G Minor for Organ and Orchestra (1927), Second Symphony for Organ (1929), and his Concerto in G Minor for Organ and Orchestra (1934), and are not specific to experience of war. If the 1941 finale begins as a "call to arms," the battle was most likely the one Dupré waged against his personal enemies: those who derided post-romanticism in music and those who destroyed Cavaillé-Coll's instruments by altering them to fit a contrary aesthetic. This fight, which consumed him during the $1920 \mathrm{~s}$ and 1930s, did not cease during the Occupation years. Only in recent decades, though, have biographers and music historians ventured to regard purely musical pursuits in Occupation-period France as legitimate activities in their own right, and to tell the entire truth about musicians' professional activities during those years.

\section{REFERENCES}

Burrin, Philippe. 1996. France under the Germans. Translated by Janet Lloyd. New York: New. Originally published as La France à l'heure allemande. Paris: Seuil, 1993.

Casanova, Nicole. 1974. Isolde 39: Germaine Lubin. Paris: Flammarion.

Chimènes, Myriam, ed. 2001. La Vie musicale sous Vichy. Introduction by the editor. Histoire du temps présent series. Brussels: Complexe.

Colleney, Christiane. 1987. "Marcel Dupré ou La Cause de l'Orgue." Special issue of Jeunesse et Orgue, nos. 65-67.

Delestre, Robert. 1952. L'Euvre de Marcel Dupré. Paris: Éditions Musique Sacrée.

Demessieux, Jeanne. 2009. "Journal (1934-1946)." In L'Orgue: Bulletin des Amis de l'Orgue 287-8:64-247.

Douglass, Fenner. 1999. Cavaillé-Coll and the French Romantic Tradition. New Haven, CT: Yale University Press.

Dunan, Élisabeth. 1951. "La Propaganda-Abteilung de France: Tâches et Organisation." Revue d'histoire de la Deuxième Guerre Mondiale 1 (4): 19-32. Dupré, Albert. 1919 Étude sur Aristide Cavaillé-Coll. Rouen: Cagniard.

29 Like Steed, other commentators have reinterpreted musical works composed in Occupationperiod France as evoking wartime experiences, whereas neither critical reception during the Occupation nor the composers' words at the time of their premieres made this connection. Regarding the myth that Messiaen's Quartet for the End of Time reflects his experience as a prisoner of war, see Simon 2009, 319-21; and Sprout 2013, 2153-2220 and 2357-65). The same sort of question might be asked of Jean Langlais's First Organ Symphony, premiered in 1943 in fulfilment of a commission from the Vichy government: for a comparison of remarks on Langlais's organ symphony by Messiaen shortly after the premiere and latter-day remarks by Langlais, see Simon 2009, 175-76. 
Dupré, Marcel. 1925. "Introduction." In Traité d'Improvisation à l'Orgue, n.p. Paris: Leduc.

—_1975. Recollections. Translated and edited by Ralph Kneeream. Melville, NY: Belwin Mills. Originally published as Marcel Dupré raconte. Paris: Bornemann, 1972.

Englert-Marchal, Jacqueline. 1985. "André Marchal Remembered by His Daughter." American Organist 19:40-46.

Guéhenno, Jean. 1947. Journal des années noires. Paris: Gallimard.

Jackson, Julian. 2001. France, the Dark Years: 1940-1945. Oxford: Oxford University Press.

Kater, Michael H. 1999. The Twisted Muse: Musicians and Their Music in the Third Reich. New York: Oxford University Press.

— 2000. Composers of the Nazi Era: Eight Portraits. New York: Oxford University Press.

— 2004. Hitler Youth. Cambridge, MA: Harvard University Press.

Massin, Brigitte. 1999. Les Joachim, une famille de musiciens. Paris: Fayard.

Murray, Michael. 1985. Marcel Dupré: The Work of a Master Organist. Introduction by Jacques Barzun. Boston: Northeastern University Press. French edition translated by Marie-Claire Cournand. Paris: Association des Amis de l'Art de Marcel Dupré, 2001.

Ochse, Orpha. 1994. Organists and Organ Playing in Nineteenth-Century France and Belgium. Bloomington: Indiana University Press.

Rasponi, Lanfranco. 1982. "Germaine Lubin." In The Last Prima Donnas, 8697. New York: Knopf.

Schwartz, Manuela. 2001. "La Musique, outil majeur dans la propagande culturelle des Nazis." Translated by Laetitia Ingrao. In La Vie musicale sous Vichy, edited by Myriam Chimènes, 89-105. Brussels: Complexe.

Simon, Yannick. 2009. Composer sous Vichy. Perpetuum mobile series: Lyon: Symétrie.

Sprout, Leslie A. 2013. The Musical Legacy of Wartime France, e-book. Berkeley: University of California Press.

Steed, Graham. 1979. "Dupré and Demessieux: The Master and the Pupil." American Organist 13: 36-37.

—_ 1999. The Organ Works of Marcel Dupré. The Complete Organ series: Hillsdale, NY: Pendragon.

Thacker, Toby. 2006. “'Renovating' Bach and Handel: New Musical Biographies in the German Democratic Republic." In Musical Biography: Towards New Paradigms, edited by Jolanta T. Pekacz, 17-41. Aldershot, UK: Ashgate.

Wright, Craig M. 1989. Music and Ceremony at Notre Dame of Paris, 500-1550. Cambridge: Cambridge University Press.

\section{ABSTRACT}

Examination of organist Marcel Dupré's collected concert programs reveals that, of 137 he performed during the German occupation, 14 bear signs of funding by the German Embassy or the military government's Propaganda Department. Dupré, though, 
would have participated in good conscience out of personal pride in France's musical past. Post-Liberation punishments of French musicians who "collaborated with the enemy" were applied so inconsistently as to explain why he thereafter suppressed the extent and nature of his Occupation-period concertizing. This fuller picture of his activities potentially sheds light on his Second World War-period compositions, particularly Évocation, op. 37.

\section{RÉSUMÉ}

Un examen des programmes de concert de l'organiste Marcel Dupré révèle que sur 137 concerts donnés pendant l'occupation allemande, 14 semblent avoir été financés par l'ambassade allemande ou par le département de la propagande du gouvernement militaire. Pourtant, Dupré aurait participé aussi à l'expression d'une bonne conscience nationale à travers sa fierté personnelle pour le passé musical français. Les condamnations des musiciens «ayant collaboré avec l'ennemi » pendant la période post-libération n'ayant pas été effectuées systématiquement, Dupré semble avoir masqué l'étendue et la nature de ses activités de concert pendant l'occupation. Ce portait plus complet de ses activités permet de renouveler notre compréhension de ses compositions pendant la Deuxième uerre mondiale, en particulier sa pièce Évocation, op.37. 